المجلة العربية لبحوث الاعلام والاتصال - : العدد 19 - أكتوبر / ديسمبر - IV

\title{
Body image in Egyptian magazine covers: A visual and textual content analysis
}

A comparative study between the coverage of "AlShorouk" \& "ElMasry elyoum" newspapers

\section{Sara Elmaghraby}

Ph.D. in Journalism

Faculty of Mass Communication - Cairo University, Egypt

\section{Introduction:}

Body image has emerged as the main element of mental and physical well-being. It is defined as the beliefs a person has about how he/she looks, the feelings they have about their looks as well as the perceptions about their bodies. Body image is defined as the way a person perceives weight, body size and appearance. (Pompper \& Koenig, 2004) The term body image appeared in 1935 by Paul Schilder who talked about schizophrenia and its effect on not recognizing one's body. Some other terms appeared in the following years such as body dissatisfaction and body image distortion.

Many factors affect the body image such as the memories someone has of himself, his/ her personal experiences, the society, and the culture. The media plays a significant role in body image. It is known from sociocultural theory that a growing number of studies address the question of whether the Body Perfect ideals in the mass media are the main risk factor for negative Body image, especially for women. (Dittmar, 2009) According to Cultivation Theory and Social Learning Theory, 2002 suggest that the repeated exposure to media content leads viewers to begin to accept media portrayals as a representation of reality. 
In a meta-analysis of 25 studies, Groesz et al. concluded that body image is more negative among less than 19 years after they viewed thin media images. The sociocultural perspective that "mass media promulgate a slender ideal elicits body dissatisfaction." (Groesz, Levine, \& Murnen, 2002) Fardouly et. Al concluded in their study that the exposure to traditional types of media can increase body image in young women (Fardouly, Diedrichs, Vartanian, \& Halliwell, 2015) Schooler`s study revealed that consistent representation on TV constructs a reality that viewers adapt as their reality. The more viewers watch TV and music videos and soap opera the more the level of body dissatisfaction. His study revealed that beauty ideal presented in mainstream media is thin and white models. (Schooler, 2004)

Magazine covers should in a very short time generate the attention to pass by, should include little but attention-grabbing elements like photos, short texts and the logo of the magazine with attractive colors. Normally magazine covers include on one side superstars portraits: personal, group of superstars, personalization which are the most dominant type, explain positive connotations about the superstar, and personalization strategies (photo and name). On the other side, they include themes that introduce the superstars positively.

Magazine Covers as one of the culturally fueled vehicles of social mediation are one of the most prominent media that presents body image. In the twentieth of the last century, women on the magazine covers were looking "flat chested, skinny and hipless" (Pompper \&

\section{Koenig, 2004)}

First researchers on body image on magazine covers are the studies of Gartinkel, Schwartz, and Thompson (1980) who have chosen a time span of twenty years to analyze the body shape on Playboy magazine and on six other popular women's magazine. They concluded a decrease in the measurements of the women and an increase in the diet articles published in these magazines. Wiseman et al. repeated the first research and revealed the same results. (Wiseman et al 1992) In Anderson and DiDomenico a comparison was held between women's and men's magazines published in 1987. This study revealed a bigger number of articles on diet published in women's magazines compared to men's. (Anderson and DiDomenico 1992) The results of Nemeroff et al. were the same. Women's magazine sample of this study published more articles about diet and fitness if compared to men's. (Nemeroff, Stein, Diehl and Smilack 1994 in (Cusumano, 1997)

Malkin et al. 1999 content analysis of 69 American women magazines revealed that 94\% displayed a thin model in the cover. Grabe et. Al tested 77 studies on body image and concluded that studies on magazines and body image are the biggest number (Grabe, Ward, \& Hyde, 2008) Studies on body image in magazine covers revealed a strong connection between body dissatisfaction and idealized body images on magazine covers. Using the Feminist theory, three articles published on body image distortion in 1994 on fitness magazine covers (Self, Shape and the New Weekly) revealed an 
المجلة العربية لبحوث الاعلام والاتصال - : العدد 19 - أكتوبر / ديسمبر - IV

ideal body image of women (Markula, 2001). A number of surveys with women revealed similar results. In a survey of college students of different origin, data was collected on media exposure to magazines, awareness of societal ideals and appearance, and internalization of the sociocultural messages. It revealed that Hispanic women compare their body image to the images published in magazines Women's magazines. They overvalue thin bodies and consider as a start of a happy life. (Pompper \& Koenig, 2004)

Nowadays, in the digital age and image sharing, younger generations tend to care about body image on the social networking sites and to create an ideal body image through filters and Photoshop and editing soft wares. This could lead to more body image dissatisfaction among users of social networking sites. (Body Image)

There is no doubt that literature has focused more on women's body image compared to men`s. Agliata et. Al were some of the few who conducted a survey on male audiences exposing half of 158 to TV advertisements with the ideal male body and the half to the neutral body. Results showed that these participants became significantly more depressed and had higher levels of muscle dissatisfaction than the ones exposed to neutral ads. (Agliata \& TantleefDunn, 2004) According to the Objectification Theory 1997, the experiences of sexual objectification socialize women to engage in self-objectification. (Harper \& Marika, 2008) Women are subject to cultural and interpersonal experiences in which female body is inspected evaluated and treated as subject to cultural and interpersonal experiences if compared to men.

\section{Theoretical Approach}

According to the "Integrated Framework for Visual Social Research", three themes should be taken into consideration when analyzing visual elements in the social sciences. The Origin and the nature of the visual, research focus and design, and format and purpose. This paper is applying this framework. Magazine Covers that are the primary source of this paper are considered according to this framework an existing visual material or socalled found visuals. The production of the data is not controlled by the researcher and is very professional. They could as well offer insights about society and reflect norms and values. The Referent or the Subject of the Research includes Visual "material culture includes artifacts and objects (home settings, etc.) and larger visible structures (urban area) that provide information and details about the material and immaterial traits of society. Immaterial traits could include norms and values, rituals and activities of the society and some behavior done by the people. The Visual Medium and Technique used in this study is a photographic representation and camera-based imagery. The Research Focus of this paper is a detailed analysis of the visual product and the verbals that accompany this product.

When analyzing a visual product, the researcher has to be aware of the depicted (the referent) and the depiction (the visual representation). The analysis could be based on straightforward ways as the number of people 
depicted etc. or may need more interpretive decoding. This operationalization could be implicated at the whole or at smaller parts of the visual product (handshakes etc.) The researcher could then conclude how certain people, in this case, the superstars on the magazine covers are represented visually and answer the question of what is depicted and how. This paper does not include an analysis of the production process and the product uses and does not include an analysis of the feedback towards the visual product. (Placeholder1; Pauwels, 2010)

The "Integrated Framework of Visual Social Research" suggests the application of theories that could be applied to visual products. I have chosen the Framing as a theory to be applied in this paper. According to Perloff, Framing is less concerned with the issue the media covers but with the particular ways those issues are presented (Perloff, 2014) Framing suggests the applicability of certain ways of thinking about the problem and calling attention to certain values and not others. It is, in general, a multilayered concept and has some macro aspects.

Some of the most important media frames suggested in previous studies related to the topic of body image on magazine covers are Psychological health/well-being, Body competence, Commercialism, Spirituality, and Social Activism, Weight and physical appearance, Physical health, and well-being and Sports/ athletics/movement. (Webb et al. 2017) Four frames were determined in previous research about the "new women": the Diva (film star), the Garconne (man-like), the Girl (sportive and active), the kid woman or " Kindfrau" (naïve and shy ) and the businesswoman p. 272 Visual media frames in specific are manifested in a number of images in a discourse that shows similar possible meanings of a theme (Perloff, 2014) p.85 These frames are characterized by a group of images with the same model of elements. They could only be understood when several images of a discourse are identified. The meaning of these frames is, therefore, relying on the context. The analysis of separate images alone in separation to the context will lead to prototypes. According to the theory, there are two types of content of visual frames: they are either generic (human interest, conflict, proximity etc.) or theme specific (related to a topic and a story)

(Mueller) determined three levels of analysis of visual products. The first level of the analysis is the structure of surface "Oberflaechenstruktur". This includes the formal criteria of the visual product " Formally Gestaltungsmerkmale", objects, and relations. The second level of analysis is the detailed structure "Binnenstruktur" or the image content (symbols and stereotypes), semi-manifest variables (image content of symbol and stereotypes, image types, and image tendencies (negative-positive)). The third level of analysis is the deep structure "Tiefenstruktur" or the meaning and the possible explanation of the image. (Mueller)

The visual content analysis is determined by two factors: the first is the textual context (captions and texts in the image or accompanying headlines); the second is the context of the receptionist, the reader, or the 
المجلة العربية لبحوث الاعلام والاتصال - : العدد 19 - أكتوبر / ديسمبر - IV

coder. The content analysis of visual media frames was only studied in relation to a specific discourse, theme, stereotypes, and image types. The study of the relation between text-image should be extended as well as the production (photographer) and the reception (reader). It should also process a large number in an easy way quantitatively as suggested by Grittmann (2007) and Geise and Roessler (2012).

The analyzed data should be analyzed with frame elements: the events, the actors, the actions, the interactions, the problems, the objects). These frame elements change to frames (Economy) and sub-frames (new products). These frames form a frame system which leads to a quantitative evaluation. (Marquart \& Matthes, 2013)

\section{Research Objectives:}

This study aims to answer the main question of how magazine covers depict body image visually and verbally. In order to answer this question some subquestions are answered:

RQ1: What is the visual content of the magazine covers concerning body image?

RQ2: What is the textual content of the magazine covers concerning body image?

\section{Sample}

The sample was derived from cover images of different magazines. This resulted in a total of 40 magazine covers representing a number of magazines: Akher Saa, Hawaa, Nisf Aldunya, Almosawer, October, Al Ahram Alriyadi, and Rose Al Youssef. Here a synopsis about each of the sample of the analysis.
October magazine: a weekly Arabic political magazine published in Egypt. It is one of the state-owned publications in the country and based in Cairo. October was established by Dar Al Maarif group in 1976.

Al Musawar magazine: a weekly Arabic political magazine. The weekly is a state-owned publication. Its headquarters is in Cairo. It was launched as a weekly in 1925. The founder was George Zidan. Since 1960 the weekly has been owned by the Egyptian government and the publisher became Dar Al-Hilal publishing house.

Rosa Al Yousef: a weekly Arabic political magazine published in Egypt. The magazine was named after its founder Rosa Al Yousef, and the first issue was published on 26 October 1925. The magazine started as a cultural and literary publication by Rosa Al Yousef but became a political magazine in 1928. The magazine had a leftist leaning during the presidency of Nasser and Sadat.

Hawaa: (Meaning Eve in English) is an Arabic language weekly women's magazine published in Cairo, Egypt. The magazine is modeled by other women's magazines in Arab countries. It was Egypt's first women magazine, founded in 1954 by Amina Al Said, an Egyptian journalist, and feminist. She was the first editor in chief of the weekly and served in the post from 1954 to 1969. She was also the first female editor in chief in Egypt and the first female chair of a publishing house, Dar al-Hilal in Egypt.

Nesf El Donia: (Meaning half of the world in English) is an Arabic weekly women's and political magazine published in Egypt. It was 
first published in 1989. It's published by Al Ahram publication group, and its editors in chief are appointed by the state.

$\mathrm{Al}$ Ahram Al riyadi: a weekly sports magazine published from Al Ahram institution.

\section{Methodology:}

This study was designed on different stages. In stage 1 all Egyptian magazines in Egyptian market were collected and filtrated into six magazines that represent different types of magazines: women, generally, art and sports magazine. An analysis of 40 magazine covers is conducted a visual and a textual content analysis is conducted on the magazine covers (Step 2).

The total number of captions of each cover was counted and each individual caption was coded to fit into three media frames: Human interest, conflict, and prominence. These frames included based on previous literature and others developed during the preliminary coding guide. In the analysis, the images of female and male cover models were analyzed. Visual images (cover models), as well as text (cover captions), were analyzed. Three levels of analysis were conducted on the data: The surface structure analysis (objects and persons), the detailed structure analysis (symbols and stereotypes etc.), and the deep structure analysis (the meaning (Mueller).

A 9-category of body image analysis is conducted as follows:

1. What is the visual content of the magazine covers concerning body image: 1.1. Who is depicted?
1.2. What is the profession of the depicted?

1.3. What is the age of the depicted?

1.4. What are the gestures of the depicted?

1.5. What are the postures of the depicted?

2. What is the textual content of magazine covers concerning body image?

2.1. What are the themes tackled?

2.2. What are the captions used?

2.3. What are the generic frames used?

2.4. What are the positive and negative descriptions given?

\section{Findings}

As explained in the methodology, this study aims at answering how men and women are depicted on Egyptian magazine covers through an analysis of the content and the visuals.

RQ1: What is the visual content of the magazine covers concerning body image?

1.1. Who is depicted?

Table 1. Gender depicted people on magazine covers

\begin{tabular}{|l|l|l|l|l|}
\hline & Female & Male & Both & Total \\
\hline Number & 13 & 16 & 11 & 40 \\
\hline Percentage & 32.5 & 40 & 27.5 & 100 \\
\hline
\end{tabular}

As shown in Table 1. Men are present in the analyzed magazine covers with $40 \%$, women with $32.5 \%$ and both men and women with $13.75 \%$. As seen in Table 1, male models are the most present in the analyzed magazine covers with $40 \%$ of the total number of covers, second comes women on the covers with $32.5 \%$ then both genders in the same cover in third place with $13.75 \%$ of the total.

1.2. What is the profession of the depicted? 
المجلة العربية لبحوث الاعلام والاتصال - : العدد 19 - أكتوبر / ديسمبر - IV

Table 2. The profession of people depicted on magazine covers

\begin{tabular}{|l|l|l|l|l|l|}
\hline & $\begin{array}{l}\text { Artists, } \\
\text { singers, and } \\
\text { actors }\end{array}$ & Politicians & $\begin{array}{l}\text { Football } \\
\text { players }\end{array}$ & $\begin{array}{l}\text { Models and } \\
\text { success } \\
\text { stories }\end{array}$ & total \\
\hline Number & 37 & 15 & 13 & 8 & 73 \\
\hline Percentage & 50.68 & 20.54 & 17.81 & 10.96 & 100 \\
\hline
\end{tabular}

Artists, singers, and actors come in first place with over half of the sample of the study. In the second place, comes politicians with $20.54 \%$ most importantly the Egyptian President and the Prime Minister. Then are football player especially Mohamed Salah and other members of the national football team. In fourth place are models (that demonstrate clothes and new fashion trends) as well as ordinary people who have had a success story that the magazine wants to highlight (A woman who works as a prison guard or a police officer who was killed by a terrorist)

1.3. What is the age of the depicted?

Here I present some examples of the different age groups present in the analyzed magazine covers.

Fig.1. Example for kids on magazine covers

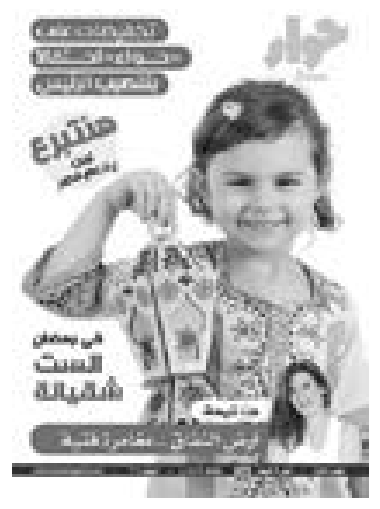

This is the only example for kids on magazine covers published in Hawaa Magazine. This kid is celebrating Ramadan holding a lamp and wearing traditional Egyptian clothes. In Fig.1. it is seen that this little girl supports collecting funds to supporters of Egypt. (Cover page, Hawaa, 2018)

\section{Fig.2. Example for youth on magazine covers}

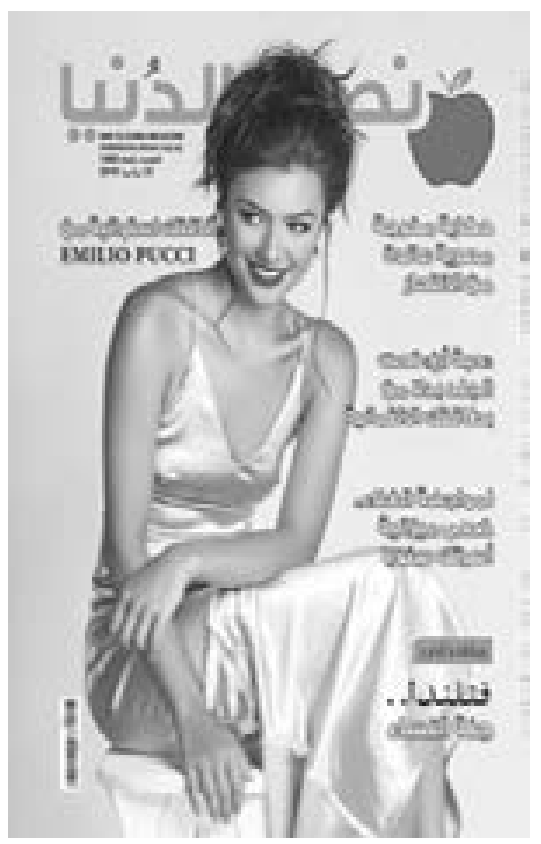

Most of the analyzed magazine covers depict women and men who are middle-aged. In Fig.2. Nisf Al Dunia depicts a middle-aged woman on the cover page that talks about exotic fashion trends for women. (Cover page, Nisf Aldunya, 2018) 
Fig.3. Example for olds on magazine covers

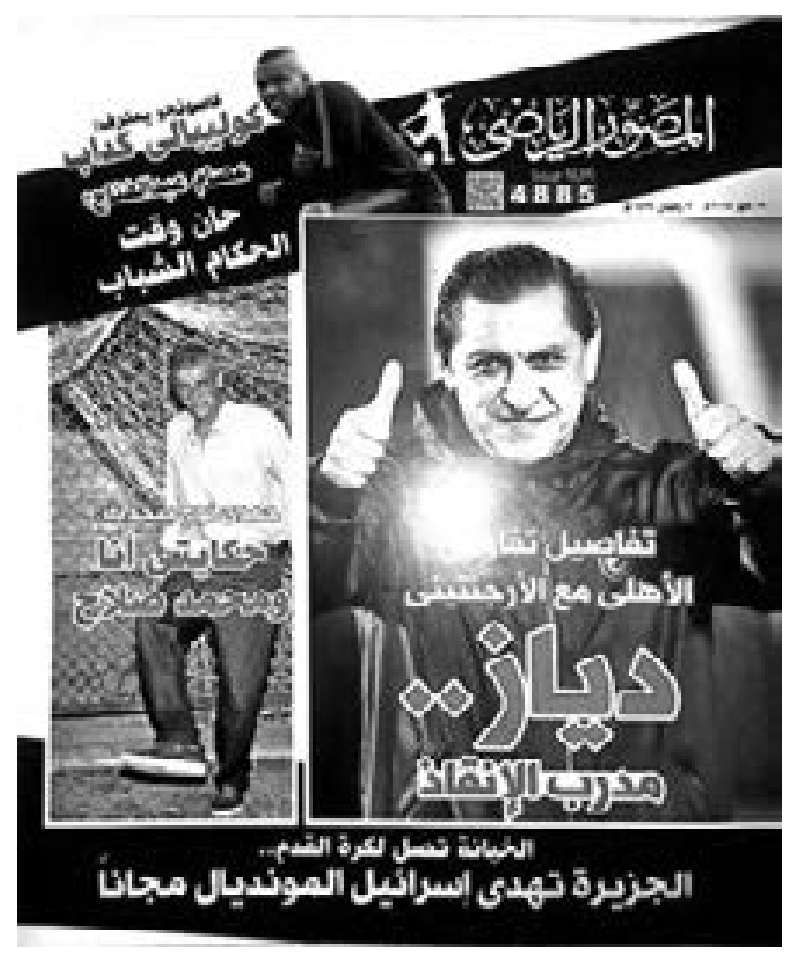

As seen in Fig.3. details are given about negotiations between the Argentinian coach Diaz and Al Ahly club. He is depicted giving a thumb up smiling wearing a blue waterproof jacket with his hair combed seemingly over 50 years old. (Cover page, Almosawar Alreyadi, 2018)

1.4. What are the gestures of the depicted?

There are different gestures of the people depicted on the analyzed magazine covers. These gestures are Happiness, Attractiveness, Angry, Disappointment and Seriousity. Here are some examples of these gestures.
Fig.4. Example for serouisity on magazine covers

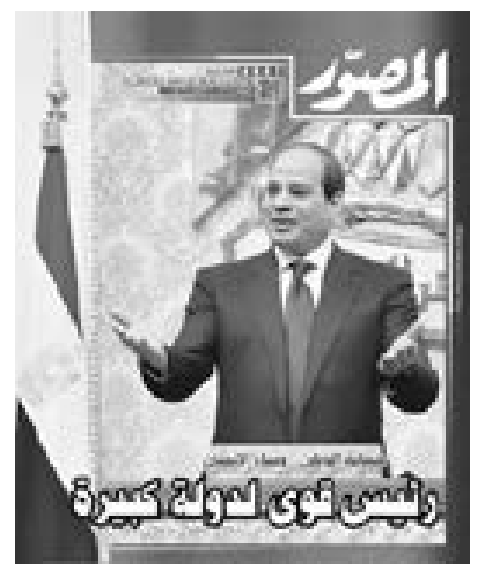

Opening his hands with a little and serious smile Al Sisi the Egyptian president of Egypt is depicted on the cover of Al Mussawar magazine. He wears a tie and a suit all in blue giving a serious and professional impression.

Fig.5. Example of Attractiveness on magazine covers

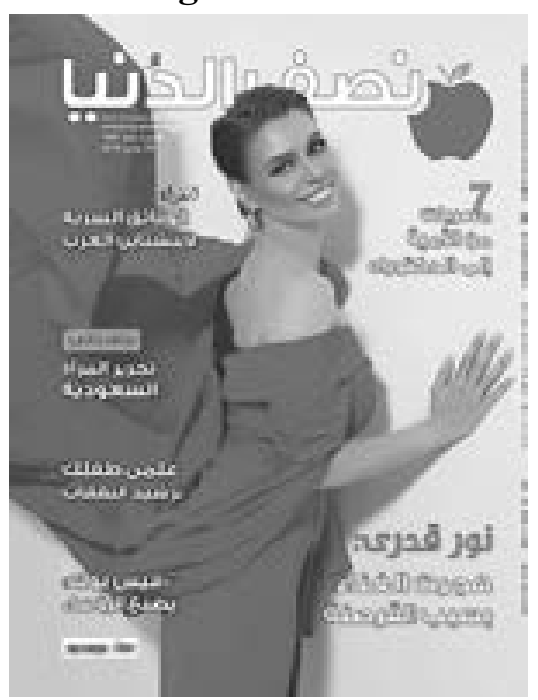


المجلة العربية لبحوث الاعلام والاتصال - : العدد 19 - أكتوبر / ديسمبر - IV

In Fig.5. the actress Nour Kadry is depicted smiling at the readers wearing a red dress. She is quoted:" I have quit singing because of hackers". She looks with a tidy straight hair, tanned skin, wearing full makeup and big earrings. (Cover page, Nisf Aldunya, 2018)

\section{Fig.6. Example for Anger}

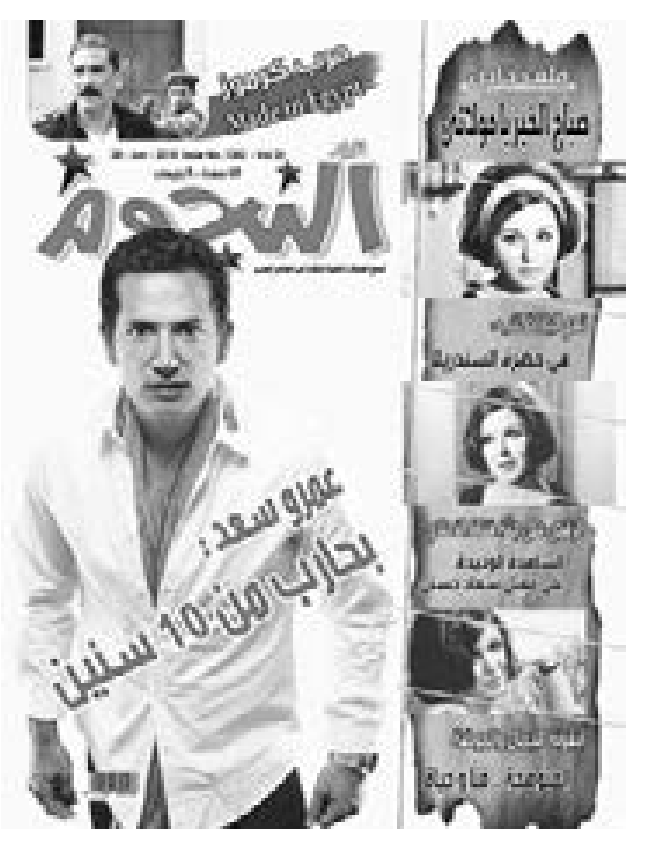

As seen in Fig.6. the Egyptian actor Amro Saad is depicted with an angry gesture that goes along with the textual caption that is accompanying the visual. The actor looks angrily at the reader in a half body image leaning to the front as if he threatens the reader or is in the middle of a fight. The quote taken from the actor is that he has fought for 10 years (to arrive at the point where he stands nowadays.) (Cover page, Alnogoum, 2018)
Fig.7. Example of Disappointment

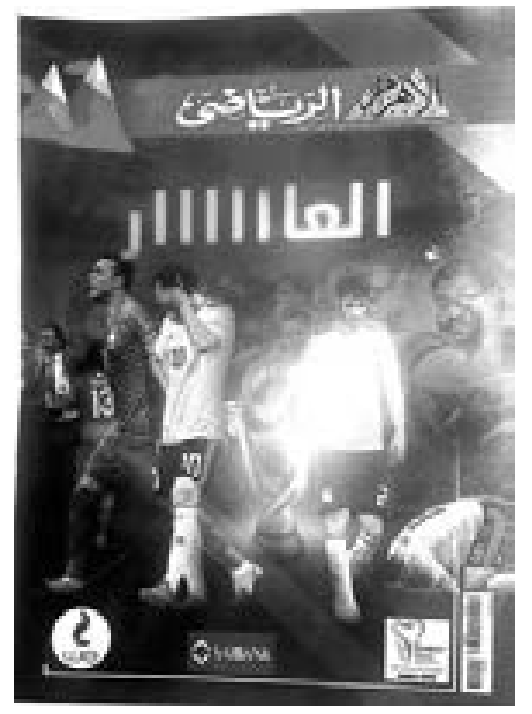

Fig.7. is a good demonstration of sadness and disappointments on magazine covers. Al Ahram Al riyadi covers the loss of the national team in the World Cup. The designer of the cover chose to write the word Shame and to repeat the letter several times to show how severe and bad the situation is. Gestures of sadness and disappointments are seen on a red background on the cover while the goalkeeper and the players, as well as the audiences, are crying and screaming. (Cover page, Al Ahram Alriyadi, 2018)

1.5. What are the postures of the depicted? According to the theory of social distance, close-ups are nearer to the viewer that long shots. The analyzed magazine covers differed from full body images to half body or torso and full face images. Here are some examples of different postures in the analyzed covers. 
Fig.8. Example for full face

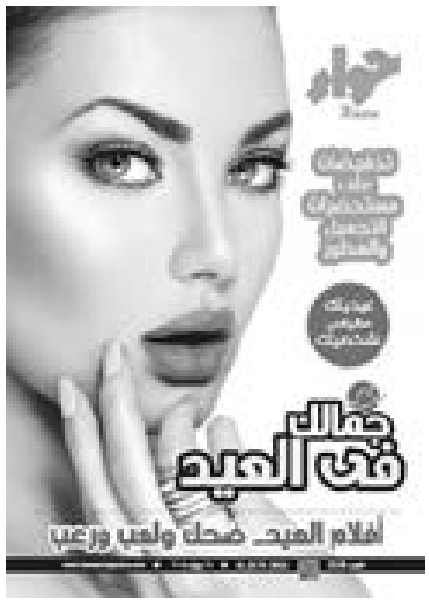

As seen in the cover of Hawaa about the beauty of women in Eid a close up on a face with colorful makeup helps to explain the idea of the text. (Cover Page, Hawaa, 2018)

Fig.9. Example for torso

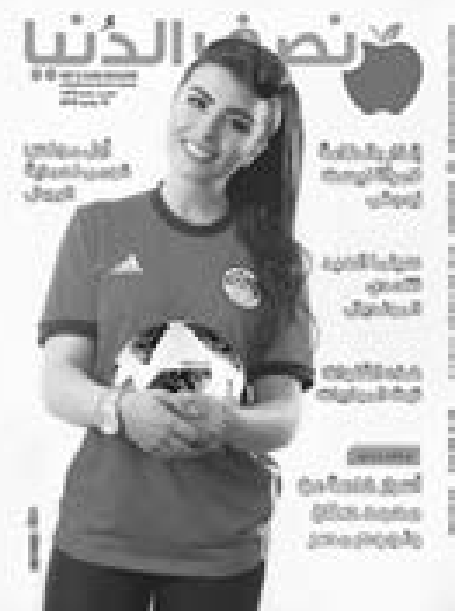

On the contrary, some distance is taken to this image that is taken until the hips or torso to focus more on the outfit the model wears and the ball she holds rather than focusing on her face (Cover page, Nisf Aldunya, 2018)

RQ 2: What is the textual content of magazine covers concerning body image?

1.1. What are the themes tackled?

Table.3. Themes tackled on magazine covers

\begin{tabular}{|l|l|l|l|l|l|l|l|l|l|l|}
\hline & $\begin{array}{l}\text { Political } \\
\text { stories }\end{array}$ & \multicolumn{2}{l|l|l|l|l|l|}{$\begin{array}{l}\text { Insider } \\
\text { stories }\end{array}$} & \multicolumn{2}{l}{$\begin{array}{l}\text { Social } \\
\text { stories }\end{array}$} & \multicolumn{2}{l|}{ Sports } & \multicolumn{2}{l|}{ Fashion } \\
\hline & M & W & M & W & M & W & m & w & m & w \\
\hline Number & 12 & 0 & 6 & 8 & 1 & 3 & 7 & 0 & 0 & 3 \\
\hline Percentage & 30 & 0 & 15 & 20 & 2.5 & 7.5 & 17.5 & 0 & 0 & 7.5 \\
\hline
\end{tabular}

As seen in Table 3. insider stories ranked first representing $35 \%$ of the analyzed covers magazine covers. Stories about failure in love stories or gossip about superstars including their personal life are put first in the analyzed covers.

\section{Fig.10. Example of insider stories}

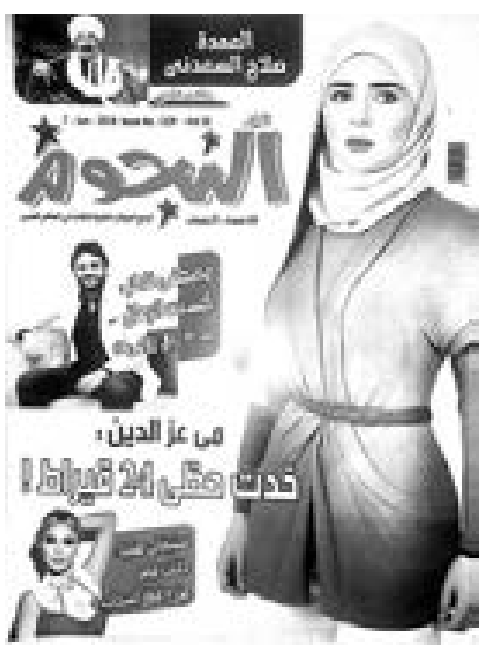

As seen in Table 3. women are mainly present in the insider stories. In Fig.10. published 
المجلة العربية لبحوث الاعلام والاتصال - : العدد 19 - أكتوبر / ديسمبر - IV

in Akhbar Alnogoum an interview with the Egyptian actress Mai Ezz Eldin is conducted and she is quoted: "I am super lucky." (Cover page, Akhbar Alnogoum, 2018)

The second rank is for political stories (12 magazine covers $30 \%$ of the analyzed covers). These stories are mainly about the statement given from or about the president, the prime minister or the government.

\section{Fig.11. Example for political stories}

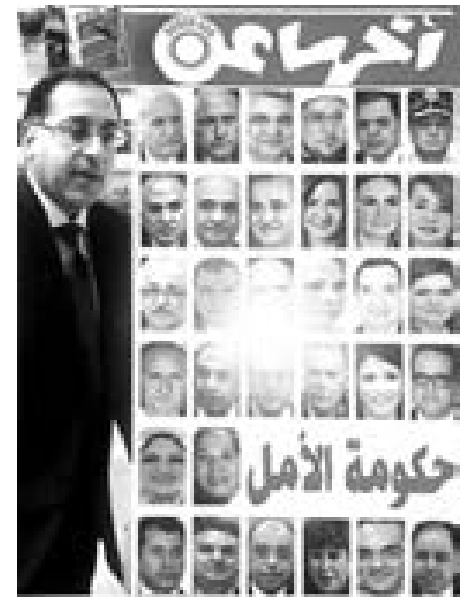

As seen in Fig.11. the magazine cover of Akher Saa depicts the prime minister and calls his government the government of hope. It is also seen that the majority of small photos seen on the cover are men photos which reflect the reality of the underrepresentation of women in the political life in Egypt.

In the third rank are sports stories (7 magazine covers) mainly covering the failures and success of the Egyptian national football team. Then social success stories were seen in four of the analyzed magazine covers and fashion on three of the analyzed magazine covers.

A closer look at the gender-related to themes, data reveal that on one side all magazine covers depicted only men when it comes to political content as well as sports. On the other side, all magazine covers about fashion depicted women. Women were more depicted in magazine covers about love stories, celebrities and insider stories (8 to 6) as well as in social success stories ( 3 to $1)$.

1.2. What are the captions used?

When analyzing a Visual product, one cannot deny the importance of the text that accompanies the image especially on magazine covers where the text gets special effects of size and color to gain attractiveness. The texts on the magazine covers could be categorized into three categories quotes from celebrities, news, and comments on the news.

Quotes from celebrities are normally special statements of interviewed stars that are published on the cover. Some examples for these quotes are the actress Nour saying:" My love story to Raheem is complicated", the singer Algasmy saying: "I wish I could have been a soldier", the actress May Ezz El Din:" I am fully lucky", Amir Karrara saying:" My success is not a coincidence Salah Mohsen: Cooper disappointed me" and Heba Magdy: "My husband convinced me to take roles that I hate."

Sometimes the magazine prefers to publish news headlines on their covers whether political or insider news. Some examples for news are "The President spends the first day with martyrs families", "Details about Al Ahly approaching 
the rescue coach Diaz", and "Zap Tharwat discovers the secret of visiting a psychiatrist".

In other times, the magazine covers include a comment on news from the magazine`s perspectives. Some example could be: " $30^{\text {th }}$ of June a story of people", "Samia Kamal.... A story of 25 years of taming prisoners"," Shame", "A martyrs will: The country is valuable ... let us sacrifice our souls" and "The government of hope." It is clear that when commenting on the news, the magazine editor chooses symbols and metaphors to create attractiveness to the cover.

1.3. What are the generic frames used?

Table.4. Generic Frames in magazines

covers
\begin{tabular}{|l|l|l|l|l|l|l|}
\hline & Human interest & Conflict & \multicolumn{2}{l|}{ Prominence } \\
\hline & M & W & M & W & m & W \\
\hline Number & 24 & 9 & 4 & 0 & 3 & 0 \\
\hline Percentage & 60 & 22.5 & 10 & 0 & 7.5 & 0 \\
\hline
\end{tabular}

As shown in Table 4, the human interest frame comes in the first place compared to the frame of conflict and prominence. Around $82.5 \%$ of the analyzed magazine covers could be categorized as human interest stories, while only $10 \%$ of the covers contain conflict and $7.5 \%$ are about politicians who are prominent.

Fig.12. Example for Human Interest frame

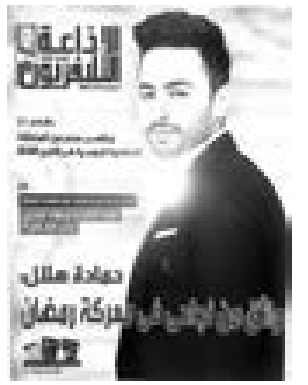

The Egyptian singer and actor, Hamada Helal, gives an exclusive interview to the magazine declaring that he is sure to succeed in the competition between actors during the month of Ramadan. The singer is depicted wearing a black suit, having a fresh haircut and neat with a beard while not smiling and looking seriously at the camera. The image of the singer is a half body alone on the cover.Fig.12. (Cover page, Radio and Television Magazine, 2018)

Fig.13. Example for the Conflict Frame

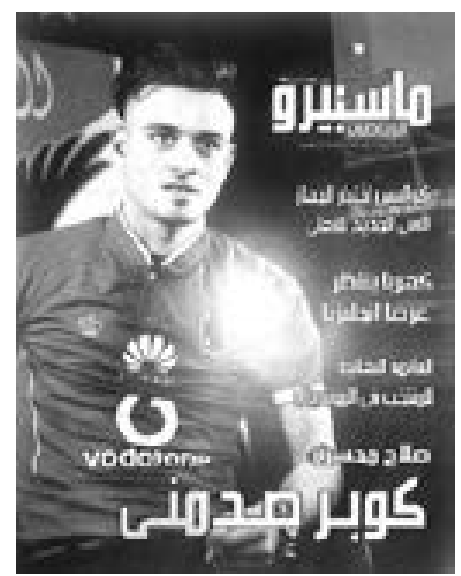

In Fig.13.the conflict between the Egyptian football player Salah Mohsen and the national team football coach Cooper is explained. The football player admits that the coach Cooper has shocked him. Wearing the red T-shirt of Al Ahly club on the whole cover with a fresh haircut looking neat and shaved the football player is depicted. The player looks with muscles, wearing sportswear while he runs and his eyes looking to the future. (Cover Page, Maspero Sports, 2018) 
المجلة العربية لبحوث الاعلام والاتصال - : العدد 19 - أكتوبر / ديسمبر - IV

Fig.14. Example for Prominence Frame

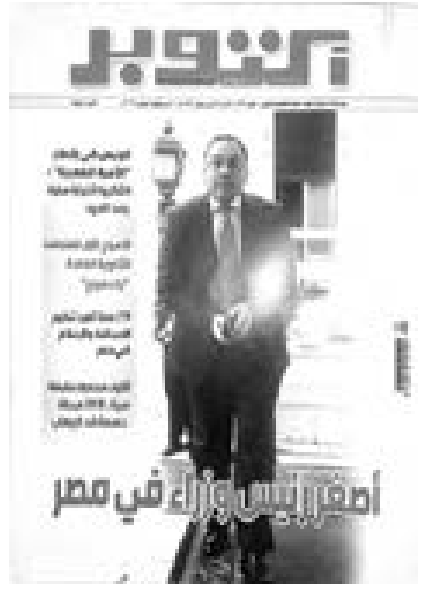

The youngest prime minister of Egypt is depicted in a full body image walking on a red carpet facing the camera. He is not smiling wearing glasses with a serious look while he holds a piece of paper and a mobile phone. The background of the image is a window, a balcony, and a lamp. The frame is prominence as a famous politician is used the full body on the cover of the magazine (Fig. 14.) (Cover page, October Weekly, 2018)

1.4. What are the positive and negative descriptions given?

Table.5. Positive and negative descriptions given

\begin{tabular}{|l|l|l|l|}
\hline Men & Negative & Women & Positive \\
\hline Positive & $\begin{array}{l}\text { The mentally } \\
\text { sick }\end{array}$ & The Diva & The Follower \\
\hline The leader & The looser & The Girl & \\
\hline The president & & The lover & \\
\hline The trainer & & The lucky & \\
\hline The martyr & & The stylish & \\
\hline The successful & & & \\
\hline The winner & & & \\
\hline The hope giver & & & \\
\hline The Pharaoh & & & \\
\hline
\end{tabular}

As summarized in Table 5, the most important positive descriptions of men in magazine covers are: men are leaders, presidents, trainers, martyr, successful, winners, hope givers, pharaohs of football. Only two negative descriptions were used to describe men these descriptions are: the mentally ill and the loser of the football match.

The positive descriptions of women are the diva, the girl, the lover, the lucky and the stylish. The negative description of men is the follower who is advised by her husband.

Fig.15. Example of positive description for men

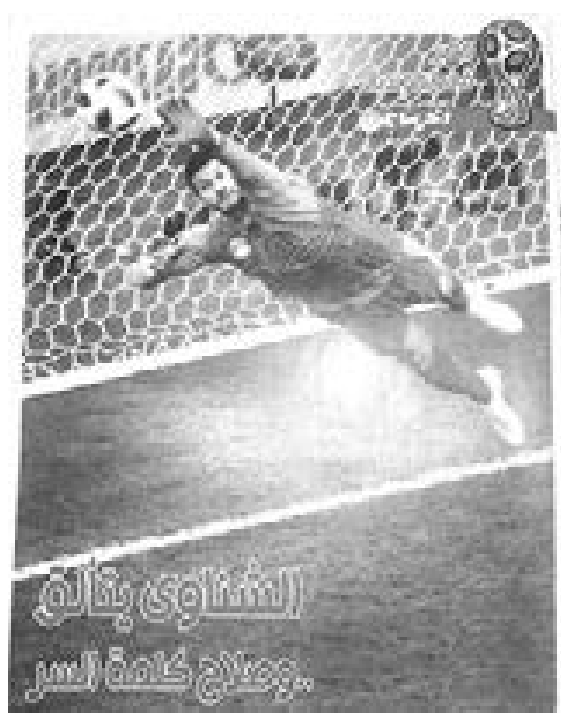

"The goalkeeper of the Egyptian national team El Shenawy shines ... and the star Mohamed Salah is the secret word" This is the cover page of Akher Saa that shows the positive connotations given to two football player describing them as successful and brilliant (Fig.15). (Cover page, 2018) 
Fig.16. Example of negative description for men

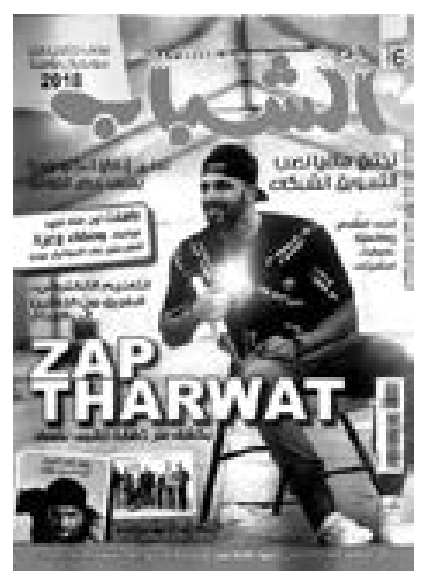

In Fig.16. a rapper called Zap Tharwat reveals that he is mentally sick and that he visits a psychiatrist. He is depicted smiling while sitting on a chair wearing white sneakers, and a reversed cap. (Cover page, Al Shabab, 2018)

Fig.17. Example of Positive description for women

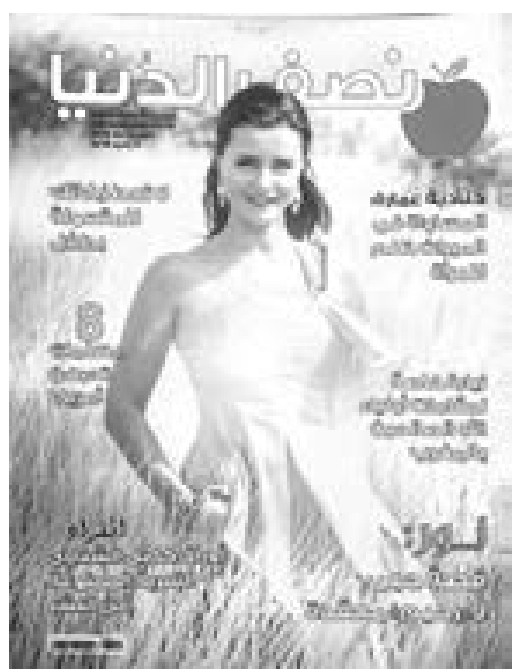

The Actress Nour explains her complicated relationship to Raheem in an exclusive interview to Nisf Eldunya in Fig.17. She is described as cheerful and happy. In a garden, she stands confidently smiling, wearing a yellow dress. She looks neat with her straight hair in a full makeup and a tanned skin. (Cover page, Nisf Aldunia, 2018)

Fig. 18. Example of a negative description for women

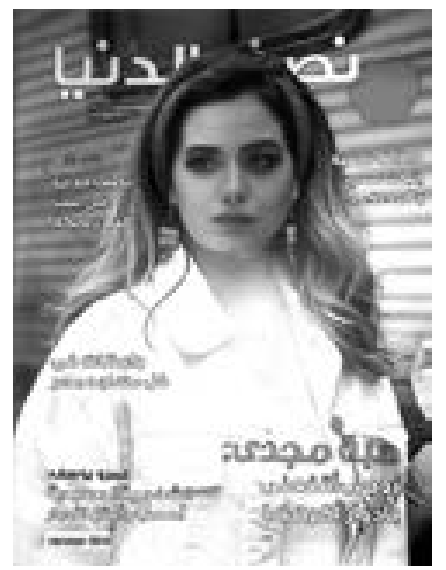

On the contrary to the previous actress, Fig. 18. demonstrates the actress Heba Magdy who says: "My husband convinced me to accept roles that I used to hate." This is a negative description to women in the magazine covers because it shows that they are followers of other people's opinion with no strong personality. (Cover page, Nisf Aldunia, 2018) 
المجلة العربية لبحوث الاعلام والاتصال - : العدد 19 - أكتوبر / ديسمبر - IV

\section{Conclusion:}

The most important findings of this paper are that men and women are depicted differently visually and textually. Different themes are connotated to men and women. Different descriptions whether positive or negative are given to men and women as well. This paper has answered the three of the analysis suggested by Mueller. The first level which is the surface structure analysis was analyzed through an indepth analysis of the objects and the persons in the magazine cover. The detailed structure analysis that includes symbols and stereotypes is discussed here. While the stereotypes of men are the strong and unbeatable, women are more stereotyped as weak and fragile. The importance of the looks of women on the analyzed magazine covers such as their makeup, their hair, their skin and dresses are very contrasting to men's body image. Men are depicted in the analyzed magazine covers in relaxed clothes and less fake settings.

When comparing my results to previous literature, I see similarities and little differences. The most relevant similarities are that women are depicted differently than men on magazine covers. The stereotypical women: the thin, the middle-aged who shows off some skin and a smile is existent in both previous literature and in this paper.

It is recommended from upcoming research to analyze in depth the effect of magazine ownership and political orientation on the depiction of men and women on their covers. It is also recommended to do studies on a comparative level for example between different Arab magazine covers or between Arab and western magazine covers. Semiotic and Semantic studies could be conducted on magazine covers as well. I also suggest further research on the readers of the analyzed magazines to ask them whether the depicted image of men and women has affected their perceptions and self-image. It is also important to conduct further research on the magazine covers designers and editors to ask about the intended and unintended messages they want to deliver for their audiences.

\section{Acknowledgment}

I would like to thank Dr. Inas Abou Youssef and Dr. Inas Abdel Hameed for giving me the opportunity to participate with this paper at the Ahram Canadian Annual Conference.

\section{Declaration of Conflicting Interest}

The author declares no potential conflict of interest with respect to the research authorship, and/or publication of this article.

\section{Funding}

The author received no financial support for the research, authorship and/or publication of this article. 


\section{References}

Cover page. (2018). Akher Saa.

Cover page, Akhbar Alnogoum. (2018, May

31). p. Issue Number 1338.

Cover page, Al Ahram Alriyadi. (2018, June

27). p. Issue Number 1488.

Cover page, Al Shabab. (2018, June). p. Issue

Number 475.

Cover page, Alhbar Alnogoum. (2018, June 7).

p. Issue Number 1339.

Cover page, Almosawar Alreyadi. (2018, May

23). p. Issue Number 4885.

Cover page, Alnogoum. (2018, June 28). p. Issue Number 1342.

Cover page, Hawaa. (2018, June 2). p. Issue Number 3216.

Cover page, Hawaa. (2018, June 30). p. Issue

Number 3220.

Cover Page, Hawaa. (2018, June 16). p. Issue Number 3218.

Cover Page, Maspero Sports. (2018, June 2). p. Issue Number 625.

Cover page, Nisf Aldunia. (2018, July 8). p. Issue Number 1478.

Cover page, Nisf Aldunia. (2018, June 1). p. Issue Number 1477.

Cover page, Nisf Aldunya. (2018, June 15). p. Issue NUmber 1479.

Cover page, Nisf Aldunya. (2018, June 22). p. Issue Number1430.

Cover page, Nisf Aldunya. (2018, June 29). p. Issue Number 1481.

Cover page, October Weekly. (2018, June 10). p. Issue Number 2172.

Cover page, Radio and Television Magazine. (2018, June 2). p. Issue Number 4342.
Agliata, D., \& Tantleef-Dunn, S. (2004). The impact of media Exposure on Males` Body image. Journal of Social and Clinical Psychology, 23(1), 7-22.

Bazzini, D., Pepper, A., Swofford, R., \& Karly, C. (2015). How Healthy are Health Magazines? A Comparative Analysis of COver Captions and Images of WOmen's and Men's Health Magazine. Sex Roles, 198-210.

Body Image. (n.d.). Retrieved September 12, 2018, from Springer: https:// link.springer.com/content/pdf/10.1007\% 2F978-981-287-087-2_74-1.pdf

Cusumano, D. L. (1997). Body Image and Body Shape Ideals in Magazines: Exposure, Awareness, and Internalization. Sex Roles, 37(9/10).

Dittmar, H. (2009). How do "Body Perfect" ideals in the media have a negative impact on body image and behaviors? Factors and Processes related to Self and Identity. Journal of Social and Clinical Psychology, 28(1), 1-8.

Engeln-Maddox, R. (2005). Cognitive Responses to idealized Media images of women: The relationship of social comparison and critical processing to body image disturbance in college women. Journal of Social and Clinical Psychology, 24(8), 1114-1138.

Fardouly, J., Diedrichs, P. C., Vartanian, L., \& Halliwell, E. (2015). Social comparisons on social media. The impact of Facebook on young women's' body image concerns and mood. Body Image, 13, 38-45.

Goodnow, T. (2017). Signs of the Apocalypse: An Analysis of Trump Magazine Covers during the 2016 Presidential Campaign. American Be- 
المجلة العربية لبحوث الاعلام والاتصال - : العدد 19 - أكتوبر / ديسمبر - IV

havioral Scientist, 1-10.

Grabe, S., Ward, M., \& Hyde, J. S. (2008). The Role of the Media in Body Image Concerns among Women: A Meta-Analysis of Experimental and Correlational Studies. Psychological Bulletin, 134(3), 460-476.

Groesz, L. M., Levine, M. P., \& Murnen, S. K. (2002). The Effects of Experimental Presentation of Thin Media Images on Body Satisfaction: A Meta-Analytic Review. International Journal Eat Disorder, 1-16.

Harper, B., \& Marika, T. (2008). The Effect of Thin Ideal media images on Wome's Self-Objectification, Mood and Body Image. Sex Roles, 58, 649-657.

Jewitt, T. V. (2004). Visual Meaning: A Social Semiotic Approach. The Handbook of Visual Analysis (pp. 134-155). Cape Town: Sage Publication.

Leath, V., \& Lumpkin, A. (1992). An Analysis of Sportswomen on the covers and in the feature articles of women's sports and fitness magazine, 1975-1989. Journal of Sport, 121-126.

Markula, P. (2001). Beyond the Perfect Body: Women's Body Image Distortion in Fitness Magazine Discourse. Journal of Sport and Social Issues, 25(2).

Marquart, F., \& Matthes, J. (2013). Charaketriska, Inhalte und Wirkungen politischer Plakate aus Sicht der Visuellen Kommunikations- und Framingforschung: Ein Forschungsueberblick. In S. Geise, \& K. Lobinger, Visual Framing, Perspektiven und Herausforderungen der Visuellen Kommunikationsforschung.

Mueller, M. G. (n.d.). Gegenwaertige Perspektiven und Herausforderungen der Visual
Framing Forschung.

Pauwels, L. (2010). Sociological Methods and Research, 545-581.

Perloff, R. (2014). The Dynamics of Political Communication: Media and Politics in a digital age. Routledge.

Pompper, D., \& Koenig, J. (2004). Cross-Cultural- Generational Perceptions of ideal Body Image: Hispanic Women and Magazine Standards. $J$ and MC Quarterly, 81(1), 89-107.

Schooler, D. W. (2004). Who`s that Girl: Television`s Role in the Body Image Development of Young White and Black Women. Psychology of Women Quarterly, 28, 38-47.

Wall, M. (1997). The Rwanda Crisis: An Analysis of News Magazine Coverage. Gazette, 121-134.

Wasike, B. (2017). Jocks versus jockettes: An analysis of the visual portrayal of male and female cover models in sports magazines. Journalism, 1-18.

Webb, J., Vinoski, E., Wareen-Findlow, J., Padro, M., Burris, E., \& Suddreth, E. (2017). Is the "yoga Bod" the new skinny? A comparative content analysis of mainstream yoga lifestyle magazine covers. Body Image, 87-98.

Wiseman, C., Gray, J., Mosimann, J., \& Ahrens, A. (1992). Cultural expectations of thinness in women: An update. International Journal Of Eating Disorders, 11(1), 85-89. doi: 10.1002/1098-108x(199201)11:1<85::aideat2260110112>3.0.co; $2-\mathrm{t}$ 
Author biography

Sara Elmaghraby is a Postdoctoral researcher and lecturer at Journalism Department, Faculty of Mass Communication, Cairo University in Egypt. She held her Ph.D. degree in International Journalism and Visual Communication. Her research interest is Global Media, Cartooning, Journalism Studies. She also conducted some research on Ethnic and Racial Minorities as well as image studies on Islam in Western media. Her fluency in Arabic, English, and German enables her to conduct intercultural and comparative studies. Throughout the years, she participated in several international and local conferences and got awarded a DAAD scholarship and an Open Society grant. 